\title{
Effects of applying magnesium fertilizer on Chinese cabbage's yield, nutrient elements' uptake and soil's fertility*
}

\author{
Dong-Feng Huang, Li-Min Wang, Xiao-Qin Wei and Tao Luo \\ Institute of Soil and Fertilizer, Fujian Academy of Agricultural Sciences, \\ Fuzhou, 350013, China \\ E-mail: huangdf@189.cn
}

\begin{abstract}
Magnesium deficiency is a common item in red-soil vegetable field in the south of China, and it has few studies about effects of applying magnesium fertilizers on vegetable's growth this region. So, a field trial, with applying different rates of magnesium fertilizers on the basis of farmer routine fertilization, was conducted to test the effects on vegetable's yield, nutrient elements' uptake and soil's basic fertility in a red-soil vegetable field. Results showed that, with the application of magnesium fertilizer (magnesium sulfate, $112.5 \sim 450 \mathrm{~kg} / \mathrm{hm}^{2}$ ), Chinese cabbage's yield, and the amount of nitrogen, phosphorus, potassium and magnesium absorbed by vegetable were increased obviously. Moreover, the contents of total magnesium and exchange magnesium in vegetable-field soil after harvest were enhanced greatly.
\end{abstract}

Keywords: Red Soil; Vegetable Field; Magnesium; Yield; Nutrient Elements; Uptake; Soil Fertility.

\section{Introduction}

Magnesium is an important component of chlorophyll and a great impact factor for green plant's photosynthesis, thereby green pant's photosynthesis would be held back and crop's yield and quality would be decreased while soil's magnesium is deficient[1-4]. Many studies have pointed out that magnesium deficient is a common item in red-soil vegetable field in South China for its individual climate and soil property [5-7]. In the red soil region of Southern China, vegetable cropping index are increasing continuously for its rich water \& heat resources and high economic benefits. For high vegetable output, farmers widely use excess amount chemical fertilizers of nitrogen, phosphorus and potassium, but ignore the application of organic manure and magnesium fertilizers. The content of magnesium in soils is decreasing gradually while

\footnotetext{
* This work is supported by National Key Technology Research and Development Project of the Ministry of Science and Technology of China (2015BAD05B01-05, 2012BAD14B15-6); Special Project of Fundamental Research Funds for Public Welfare Research Institutes of Fujian Province (2014R1022-7).
} 
amount of magnesium has been taken out from vegetable field with vegetable products harvested. Therefore, magnesium deficiency is becoming more and more common in vegetable production in red soil region of Southern China [8].

Presently, there are few studies about effects of applying magnesium fertilizers on vegetable, in especial, that is less in red-soil region vegetable field of Southern China [8-10]. Thus, a field trial was conducted to test effects of applying different doses of magnesium fertilizers on the basis of farmer routine fertilization on yield, uptake of mineral nutrients by vegetable and soil's basic fertility after harvest. Results from this study would provide some scientific basis for the application of magnesium fertilizers in vegetable production in the red soil region of Southern China.

\section{Materials and Methods}

Trial field was located at Sixi village, Guanqiao town, Nanan city of Fujian province, Southern China. Five treatments were designed, namely:(1) Chemical fertilizers (i.e., farmer conventional fertilization, $\mathrm{N} 180 \mathrm{~kg} / \mathrm{hm}^{2}, \mathrm{P}_{2} \mathrm{O}_{5} 72 \mathrm{~kg} / \mathrm{hm}^{2}$ and $\mathrm{K}_{2} \mathrm{O} 90 \mathrm{~kg} / \mathrm{hm}^{2}$, the same below);(2) Chemical fertilizers + Magnesium sulfate $\left(112.5 \mathrm{~kg} / \mathrm{hm}^{2}\right) ;(3)$ Chemical fertilizers + Magnesium sulfate (225 $\left.\mathrm{kg} / \mathrm{hm}^{2}\right)$; (4) Chemical fertilizers + Magnesium sulfate $\left(337.5 \mathrm{~kg} / \mathrm{hm}^{2}\right)$; (5) Chemical fertilizers + Magnesium sulfate $\left(450 \mathrm{~kg} / \mathrm{hm}^{2}\right)$. Those five treatments were stood for by $\mathrm{Mg}_{0}, \mathrm{Mg}_{1}, \mathrm{Mg}_{2}, \mathrm{Mg}_{3}$ and $\mathrm{Mg}_{4}$, respectively. Each treatment had 3 replicates, and the area of each plot was $20 \mathrm{~m}^{2}$, and those plots were arranged randomly. Fertilizers used were as follows: Urea (N46\%), Ammonium phosphate (N10\%, $\left.\mathrm{P}_{2} \mathrm{O}_{5} 50 \%\right)$, and Potassium chloride $\left(\mathrm{K}_{2} \mathrm{O} 60 \%\right)$, Magnesium sulfate (including magnesium 15\%). And all fertilizers of each plot were applied as basal fertilizers, combining with soil preparation.

Chinese cabbage (Qingjiang cabbage, Brassica campestris L. ssp.) was selected as tested vegetable breed, seeded on March 30, 2014, and harvested on May 14, 2014. On harvest season, vegetable yield of each plot was measured, and vegetable's edible part was sampled.

Routine analytical methods were used for the determination of nutrient elements in vegetable samples [14]. Trial data were processed by Excel-2007 of Microsoft, and statistically analyzed by using SPSS11.0.

\section{Results and Analysis}

\subsection{Effect of applying magnesium fertilizer on yield of vegetable}

Results (Figure 1) showed that, compared with the control treatment $\left(\mathrm{Mg}_{0}\right)$, applying magnesium fertilizer treatments $\left(\mathrm{Mg}_{1}, \mathrm{Mg} 2, \mathrm{Mg} 3\right.$ and $\left.\mathrm{Mg}_{4}\right)$ could increase vegetable's yield by $12.4 \%$ 20.4\%. Among them, vegetable's yield of 
the treatment $\mathrm{Mg}_{4}$ reached at the highest.

Results of variance analysis showed that treatments of $\mathrm{Mg}_{3}$ and $\mathrm{Mg}_{4}$ could significantly $(P<0.05)$ increase vegetable's yield compared with $\mathrm{Mg}_{0}$, and the difference between treatments of $\mathrm{Mg}_{1}$ and $\mathrm{Mg}_{2}$ was not significant. And the difference was not significant among $\mathrm{Mg}_{1}, \mathrm{Mg}_{2}$ and $\mathrm{Mg}_{0}$.

Results of linear regression analysis between Vegetable yield (y, $\mathrm{kg} / \mathrm{hm}^{2}$ ) and Use rate of magnesium sulfate $\left(\mathrm{x}, \mathrm{kg} / \mathrm{hm}^{2}\right)$ showed that the relationship between those two factors could be well fit by quadratic equation with one unknown, $y=-0.53 x^{2}+60.61 x+9093\left(R^{2}=0.961 * *\right)$. And results could be concluded by above equation that, vegetable's yield would reach at the highest $\left(10825.81 \mathrm{~kg} / \mathrm{hm}^{2}\right)$ while applying the amount of Magnesium Sulfate 381.2 $\mathrm{kg} / \mathrm{hm}^{2}$.

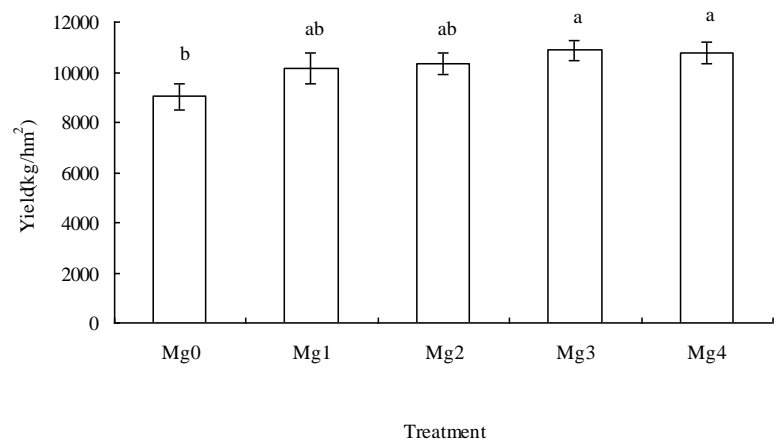

Note: Different capital and small letters indicate the difference is significant at 0.05 and 0.01 levels, respectively (inspect by LSD). The same below.

Fig. 1. Effect of using magnesium fertilizer on the yield of Chinese cabbage.

\subsection{Effects of applying magnesium fertilizer on uptake of nitrogen, phosphorus, potassium and magnesium by vegetables}

Results (Table 1) showed that, compared with the control treatment $\left(\mathrm{Mg}_{0}\right)$, applying magnesium fertilizer treatments $\left(\mathrm{Mg}_{1}, \mathrm{Mg}_{2}, \mathrm{Mg}_{3}\right.$ and $\left.\mathrm{Mg}_{4}\right)$ could significantly improve the uptake of nutrient elements of nitrogen, phosphorus, potassium and magnesium by vegetable, and the improving amplitudes were $27.7 \% \sim 42.5 \%, 30.1 \% \sim 84.9 \%, 38.0 \% \sim 80.3 \%$ and $53.2 \% \sim 131.9 \%$, respectively. Among them, vegetable's yield of the treatment $\mathrm{Mg}_{4}$ reached at the highest. Among them, the effect of $\mathrm{Mg}_{3}$ treatment on nitrogen uptake of vegetables was the best, and the effect of $\mathrm{Mg}_{4}$ treatment on $\mathrm{P}, \mathrm{K}$ and $\mathrm{Mg}$ uptake was the best.

Results of variance analysis showed that, compared with $\mathrm{Mg}_{0}$, all applying magnesium fertilizer treatments $\left(\mathrm{Mg}_{1}, \mathrm{Mg}_{2}, \mathrm{Mg}_{3}\right.$ and $\left.\mathrm{Mg}_{4}\right)$ could extreme-significantly $(P<0.01)$ improve the uptake of nitrogen by vegetable; and 
the uptakes of nitrogen for treatments of $\mathrm{Mg}_{2}, \mathrm{Mg}_{3}$ and $\mathrm{Mg}_{4}$ were significantly $(P<0.05)$ higher than treatment $\mathrm{Mg}_{1}$. On the uptake of phosphorus by vegetable, treatments of $\mathrm{Mg}_{3}$ and $\mathrm{Mg}_{4}$ were significantly $(P<0.05)$ better than others, and treatments of $\mathrm{Mg}_{1}$ and $\mathrm{Mg}_{2}$ were significantly $(P<0.05)$ better than $\mathrm{Mg}_{0}$. On the uptake of potassium by vegetable, all applying magnesium fertilizer treatments $\left(\mathrm{Mg}_{1}, \mathrm{Mg}_{2}, \mathrm{Mg}_{3}\right.$ and $\left.\mathrm{Mg}_{4}\right)$ were extreme-significantly $(P<0.01)$ better than $\mathrm{Mg}_{0}$; Treatments of $\mathrm{Mg}_{3}$ and $\mathrm{Mg}_{4}$ were extreme-significantly $(P<0.01)$ better than $\mathrm{Mg}_{2}$; and treatment of $\mathrm{Mg}_{2}$ was extreme-significantly $(P<0.01)$ better than $\mathrm{Mg}_{1}$, too. On the uptake of magnesium by vegetable, treatments of $\mathrm{Mg}_{3}$ and $\mathrm{Mg}_{4}$ were extreme-significantly $(P<0.01)$ better than others, and treatments of $\mathrm{Mg}_{1}$ and $\mathrm{Mg}_{2}$ were extreme-significantly $(P<0.01)$ better than $\mathrm{Mg}_{0}$, too.

Table 1. Effect of using magnesium fertilizer on the uptake of nitrogen, phosphorus, potassium and magnesium by vegetable.

\begin{tabular}{|c|c|c|c|c|c|c|c|c|}
\hline \multirow{2}{*}{ Treatment } & \multicolumn{2}{|c|}{ Nitrogen } & \multicolumn{2}{c|}{ Phosphorus } & \multicolumn{2}{c|}{ Potassium } & \multicolumn{2}{c|}{ Magnesium } \\
\cline { 2 - 9 } & $\left(\mathrm{kg} \cdot \mathrm{hm}^{-2}\right)$ & $\pm(\%)$ & $\left.\mathrm{kg} \cdot \mathrm{hm}^{-2}\right)$ & $\pm(\%)$ & $\left(\mathrm{kg} \cdot \mathrm{hm}^{-2}\right)$ & $\pm(\%)$ & $\left(\mathrm{kg} \cdot \mathrm{hm}^{-2}\right)$ & $\pm(\%)$ \\
\hline $\mathrm{Mg}_{0}$ & $18.9 \mathrm{Bc}$ & $\backslash$ & $1.83 \mathrm{c}$ & $\backslash$ & $38.0 \mathrm{Dd}$ & $\backslash$ & $1.82 \mathrm{Cd}$ & $\backslash$ \\
\hline $\mathrm{Mg}_{1}$ & $24.1 \mathrm{Ab}$ & 27.7 & $2.39 \mathrm{~b}$ & 30.1 & $52.3 \mathrm{Cc}$ & 37.6 & $2.78 \mathrm{Bc}$ & 53.2 \\
\hline $\mathrm{Mg}_{2}$ & $25.8 \mathrm{Aa}$ & 36.5 & $2.62 \mathrm{~b}$ & 42.7 & $60.4 \mathrm{Bb}$ & 59.1 & $3.38 \mathrm{Bb}$ & 86.2 \\
\hline $\mathrm{Mg}_{3}$ & $26.9 \mathrm{Aa}$ & 42.5 & $3.01 \mathrm{a}$ & 64.3 & $74.7 \mathrm{Aa}$ & 96.7 & $4.16 \mathrm{Aa}$ & 128.9 \\
\hline $\mathrm{Mg}_{4}$ & $25.8 \mathrm{Aa}$ & 37.0 & $3.39 \mathrm{a}$ & 84.9 & $80.3 \mathrm{Aa}$ & 111.3 & $4.21 \mathrm{Aa}$ & 131.9 \\
\hline
\end{tabular}

\subsection{Effects of applying magnesium fertilizer on soil's basic fertility}

Results (Table 2) showed that, compared with the control treatment $\left(\mathrm{Mg}_{0}\right)$, all applying magnesium fertilizer treatments $\left(\mathrm{Mg}_{1}, \mathrm{Mg}_{2}, \mathrm{Mg}_{3}\right.$ and $\left.\mathrm{Mg}_{4}\right)$ could increase vegetable-field soil's total magnesium and exchangeable magnesium by $15.8 \% \sim 68.4 \%$ and $29.0 \% \sim 119.0 \%$, respectively. And soil $\mathrm{pH}$ and the contents of organic matter, total nitrogen and available potassium were decreased a little; the content of soil's total potassium was increased a little; and the contents of total phosphorus, available nitrogen and phosphorus were increased or decreased a little.

Results of variance analysis showed that: (1) On the effect of increasing soil's total magnesium content, treatment of $\mathrm{Mg}_{4}$ was significantly $(P<0.05)$ better than $\mathrm{Mg}_{0}$ and $\mathrm{Mg}_{1}$; but the difference was not significant among $\mathrm{Mg}_{0}, \mathrm{Mg}_{1}$ $\mathrm{Mg}_{2}$ and $\mathrm{Mg}_{3}$. (2) On the effect of increasing soil's exchangeable magnesium content, treatments of $\mathrm{Mg}_{3}$ and $\mathrm{Mg}_{4}$ was significantly $(P<0.05)$ better than $\mathrm{Mg}_{0}, \mathrm{Mg}_{1}$ and $\mathrm{Mg}_{2}$; but the difference was not significant between $\mathrm{Mg}_{4}$ and $\mathrm{Mg}_{3}$ or among $\mathrm{Mg}_{0}, \mathrm{Mg}_{1}$ and $\mathrm{Mg}_{2}$. (3)On effects of other soil's basic fertility indices, such as $\mathrm{pH}$, organic matter, total nitrogen, total phosphorus, total phosphorus, total phosphorus, available nitrogen, available phosphorus, available potassium, and so on, the difference was not significant among $\mathrm{Mg}_{0}, \mathrm{Mg}_{1}, \mathrm{Mg}_{2}, \mathrm{Mg}_{3}$ and 
$\mathrm{Mg}_{4}$

Table 2. Effects of applying magnesium fertilizer on soil basic fertility.

\begin{tabular}{cccccc}
\hline Treatments & $\mathrm{pH}$ & $\begin{array}{c}\text { Organic } \\
\text { matter } \\
(\mathrm{g} / \mathrm{kg})\end{array}$ & $\begin{array}{c}\text { Total } \\
\text { nitrogen } \\
(\mathrm{g} / \mathrm{kg})\end{array}$ & $\begin{array}{c}\text { Total } \\
\text { phosphorus } \\
(\mathrm{g} / \mathrm{kg})\end{array}$ & $\begin{array}{c}\text { Total } \\
\text { potassium } \\
(\mathrm{g} / \mathrm{kg})\end{array}$ \\
\hline $\mathrm{Mg}_{0}$ & $5.42 \mathrm{a}$ & $46.6 \mathrm{a}$ & $2.9 \mathrm{a}$ & $0.91 \mathrm{a}$ & $25.9 \mathrm{a}$ \\
$\mathrm{Mg}_{1}$ & $5.41 \mathrm{a}$ & $44.5 \mathrm{a}$ & $2.6 \mathrm{a}$ & $0.92 \mathrm{a}$ & $26.1 \mathrm{a}$ \\
$\mathrm{Mg}_{2}$ & $5.38 \mathrm{a}$ & $45.5 \mathrm{a}$ & $2.8 \mathrm{a}$ & $0.91 \mathrm{a}$ & $26.9 \mathrm{a}$ \\
$\mathrm{Mg}_{3}$ & $5.33 \mathrm{a}$ & $45.4 \mathrm{a}$ & $2.7 \mathrm{a}$ & $0.89 \mathrm{a}$ & $28.2 \mathrm{a}$ \\
$\mathrm{Mg}_{4}$ & $5.25 \mathrm{a}$ & $44.9 \mathrm{a}$ & $2.8 \mathrm{a}$ & $0.89 \mathrm{a}$ & $27.2 \mathrm{a}$ \\
\hline & Total & Available & Available & Available & Exchangeable \\
$\mathrm{Treatments}$ & magnesium & nitrogen & phosphorus & potassium & magnesium \\
& $(\mathrm{g} / \mathrm{kg})$ & $(\mathrm{mg} / \mathrm{kg})$ & $(\mathrm{mg} / \mathrm{kg})$ & $(\mathrm{mg} / \mathrm{kg})$ & $(\mathrm{mg} / \mathrm{kg})$ \\
\hline $\mathrm{Mg}_{0}$ & $0.19 \mathrm{~b}$ & $16.3 \mathrm{a}$ & $37.4 \mathrm{a}$ & $326.5 \mathrm{a}$ & $25.2 \mathrm{~b}$ \\
$\mathrm{Mg}_{1}$ & $0.22 \mathrm{~b}$ & $15.8 \mathrm{a}$ & $36.5 \mathrm{a}$ & $319.6 \mathrm{a}$ & $32.5 \mathrm{~b}$ \\
$\mathrm{Mg}_{2}$ & $0.27 \mathrm{ab}$ & $16.6 \mathrm{a}$ & $36.8 \mathrm{a}$ & $318.5 \mathrm{a}$ & $40.3 \mathrm{~b}$ \\
$\mathrm{Mg}_{3}$ & $0.31 \mathrm{ab}$ & $16.7 \mathrm{a}$ & $37.1 \mathrm{a}$ & $315.1 \mathrm{a}$ & $52.5 \mathrm{a}$ \\
$\mathrm{Mg}_{4}$ & $0.32 \mathrm{a}$ & $17.1 \mathrm{a}$ & $37.5 \mathrm{a}$ & $323.2 \mathrm{a}$ & $55.2 \mathrm{a}$ \\
\hline
\end{tabular}

\section{Conclusion}

Results concluded from our field trial showed that, with the application of magnesium fertilizer (magnesium sulfate, $112.5 \sim 450 \mathrm{~kg} / \mathrm{hm}^{2}$ ), Chinese cabbage's yield increased by $12.4 \%$ 20.4\%; The amount of nitrogen, phosphorus, potassium and magnesium absorbed by vegetable increased by $27.7 \% \sim 42.5 \%, 30.1 \% \sim 84.9 \%, 38.0 \% \sim 80.3 \%$ and $53.2 \% \sim 131.9 \%$, respectively. Moreover, the contents of total magnesium and exchange magnesium in vegetable-field soil after harvest were enhanced by $15.8 \% \sim 68.4 \%$ and 29.0\% 119.0\%, respectively. Among them, treatment of $\mathrm{Mg}_{3}$ (Magnesium Sulfate, $337.5 \mathrm{~kg} / \mathrm{hm}^{2}$ ) had the best effect to improve the uptake of nitrogen absorption by vegetable, and $\mathrm{Mg}_{4}$ (Magnesium Sulfate, $450 \mathrm{~kg} / \mathrm{hm}^{2}$ ) had the best effect to improve the uptakes of phosphorus, potassium and magnesium by vegetable. Presently, it has few studies about effects of applying magnesium fertilizer on soil basic fertility of vegetable field, which need to be further strengthened in the future.

\section{References}

1. Sun N, Zeng X B, Gao J S, et al. Effects of magnesium compound fertilizer on daylily (Hemerocallis citrine Baroni) growth and soil Nutrients. Scientia Agicuhura Sinica, 2006, 39 (1): 95-101. (In Chinese)

2. Ling L L, Huang Y, Peng L Z, et al. Influence of magnesium deficiency and excess on chlorophyll fluorescence characteristics of Newhall navel orange leaves. Acta Ecologica Sinica, 2014, 34(7):1672-1680. (In Chinese) 
3. Hagstrom, G. R. Sources of fertilizer magnesium and their use[C]. Proceedings of the international symposium on the role of sulphur, magnesium and micronutrients in balanced plant nutrition, 1992: 246-256.

4. Fink, M. Feller, C. Scharpf, H. C. et al. Nitrogen, phosphorus, potassium and magnesium contents of field vegetables - recent data for fertilizer recommendations and nutrient balances [J]. Zeitschrift fur Pflanzenernahrung und Bodenkunde, 1999, 162(1):71-73.

5. Tan H W, Du C L, Zhou L Q. Effect of magnesium fertilizer on sustaining upland agricultural development in Guangxi province [J]. Better Crops International, 2000, 14(2):13-15.

6. Pan Z C. Effect of boron and magnesium fertilization on tea yield, quality and soil fertility of red-soil tea plantations. Fujian Journal of Agricultural Sciences, 2015, 30 (9):877-883. (In Chinese)

7. Xu M G. Magnesium fertilizers can not be missing in Southern Red-soil Region. Rural practical technology, 2005(7):34. (In Chinese)

8. Wang Y J, Feng Y F. Occurrence and control of magnesium deficiency in vegetable. Shanghai Vegetable, 2007(5):108,136. (In Chinese)

9. Huang H X, Chen F X, Xu M G, et al. Study on magnesium status and application technology of magnesium fertilizer in red soil region. Soil and Fertilizer, 2000(5):19-23. (In Chinese)

10. Li F S. Effects of magnesium fertilizer on crops in Red Soil Regions of China. Soil and Environmental Sdences, 2000, 9 (1):53-55. (In Chinese)

11. Mccolluch E C. Relation of Soil potassium and Magnesium to Magnesium Nutrition of Citrus [J]. Soil Sci Soc Amer Proc, 1957, 21: 85-88.

12. Yang B M, Li J Q, Yao L X, et al. Effect of potassium, calcium and magnesium on yield, quality and storage property of banana. Chinese Journal of Eco-Agriculture, 2010, 18(2):290-294. (In Chinese)

13. Zhu S, Wu G S, Cai H, et al. Effects of low magnesium on photosynthesis characteristics and antioxidant system in cucumber seedlings under low temperature. Chinese Journal of Applied Ecology, 2015, 26(5): 1351-1358. (In Chinese)

14. Lu R K. Analyzing Method of Soil Agricultural Chemistry [M]. Beijing: Agricultural Science and Technology Publishing Company of China, 2000(In Chinese) 